\title{
About authors:
}

Sharipov Aslamhon Makhmudovich, DMSc, Head of the Department of pediatric thoracoabdominal surgery;

tel.: +992907708250; e-mail: aslam72@list.ru

Bataev Saidkhassan Magomedovich, MD, PhD, Professor, Chief Researcher;

tel.: +79260169119; e-mail: khassan-2@yandex.ru; ORCID - 0000-0003-0191-1116

Giyosov Kholnazar Amonovich, Deputy director; tel.: +992918266262; e-mail: aslam72@list.ru

Sayfulloev Imatihudo Dodovich, Resident at the Department of thoracoabdominal surgery; tel.: +992918808144; e-mail: aslam72@list.ru

Zoirov Alisher Radjabovich, Doctor of the ultrasound diagnostics; tel.: +992918610723; e-mail: aslam72@list.ru

Shangareyeva Rosa Khurmatovna, MD, PhD, Professor, Professor of the Department of pediatric surgery;

tel.: +79173653226; e-mail: shanrosa@mail.ru

\section{LAPAROSCOPIC PARTIAL RESECTION OF A POST-TRAUMATIC PANCREATIC CYST WITH DISTAL ROUX-EN-Y PANCREATICOJEJUNAL ANASTOMOSIS IN A CHILD}

Sokolov Yu. Yu. 1, 2, Efremenkov A. M. 1, Tumanyan G. T. 1, ${ }^{\text {, }}$ Shapkina A. N. ${ }^{3}$, Ahmatov R. A. ${ }^{1}$, Antonov D. V. ${ }^{4}$

${ }^{1}$ Russian Medical Academy of Post-Graduate Education, Moscow, Russian Federation

2 St. Vladimir Children's Hospital, Moscow, Russian Federation

3 Institute of Surgery, Pacific State Medical University, Vladivostok, Russian Federation

${ }^{4}$ Perm State Medical University named after academician E. A. Wagner, Russian Federation

\section{МАПАРОСКОПИЧЕСКАЯ ЧАСТИЧНАЯ РЕЗЕКЦИЯ ПОСТТРАВМАТИЧЕСКОЙ КИСТЫ ПОАЖЕАУАОЧНОЙ ЖЕАЕЗЫ С НАЛОЖЕНИЕМ АИСТААЬНОГО ПАНКРЕАТОЕЮНОАНАСТОМОЗА У РЕБЕНКА}

Ю. Ю. Соколов 1, 2, А. М. Ефременков 1, Г. Т. Туманян 1, 2 , А. Н. Шапкина ${ }^{3}$, Р. А. Ахматов ${ }^{1}$, А. В. Антонов ${ }^{4}$

\section{1 Российская меАицинская акаАемия непрерывного профессионального образования, Москва, Российская ФеАерация \\ 2 Аетская городская кАиническая больница Св. ВлаАимира, Москва, Российская Фелерация \\ ${ }^{3}$ Институт хирургии, Тихоокеанский госуаарственный меАицинский университет, ВАаАивосток, Российская ФеАерация \\ ${ }^{4}$ Пермский госуАарственный меАицинский университет им. акаАемика Е. А. Вагнера, Российская ФеАерация}

Cystic formations of the pancreas in children are relatively rare. In most cases, pseudocysts arising after injury or inflammation of the gland parenchyma, are diagnosed. The article presents a clinical observation of a 7-year-old child with a post-traumatic pancreatic cyst. Conservative treatment was ineffective. The child underwent laparoscopic partial resection of the pancreatic cyst and Roux-en-Y distal pancreatojejunostomy. The selected treatment method allowed preserving the distal part of the pancreas, ensured reliable long-term drainage of the contents into the gastrointestinal tract and recovery of a child.

Keywords: children, pancreas, pancreatic injury, pancreatic pseudocysts, laparoscopy, Roux-en-Y pancreaticojejunal anastomosis

Кистозные образования поджелудочной железы у детей встречаются относительно редко. В большинстве случаев диагностируются псевдокисты, возникающие после повреждений или воспалений паренхимы железы. Представлено клиническое наблюдение посттравматической кисты поджелудочной железы у 7-летнего ребенка. Консервативное лечение оказалось неэффективным. Ребёнку было выполнено лапароскопическое частичное иссечение кисты с наложением дистального панкреатоеюноанастомоза на отключённой по Ру петле. Выбранный метод лечения позволил не только сохранить дистальную часть поджелудочной железы, но и обеспечить надежный длительный дренаж содержимого в просвет желудочно-кишечного тракта с выздоровлением пациента.

Ключевые слова: дети, поджелудочная железа, травма поджелудочной железы, псевдокиста, лапароскопия, панкреатоеюноанастомоз 
For citation: Sokolov Yu. Yu., Efremenkov A. M., Tumanyan G. T., Shapkina A. N., Ahmatov R. A., Antonov D. V. LAPAROSCOPIC PARTIAL RESECTION OF A POST-TRAUMATIC PANCREATIC CYST WITH DISTAL ROUX-EN-Y PANCREATICOJEJUNAL ANASTOMOSIS IN A CHILD. Medical News of North Caucasus. 2019;14(3):547-550. DOI - https://doi.org/10.14300/mnnc.2019.14137

Для цитирования: Соколов Ю. Ю., Ефременков А. М., Туманян Г. Т., Шапкина А. Н., Ахматов Р. А., АнтоНОВ Д. В. ЛАПАРОСКОПИЧЕСКАЯ ЧАСТИЧНАЯ РЕЗЕКЦИЯ ПОСТТРАВМАТИЧЕСКОЙ КИСТЫ ПОДЖЕЛУДОЧНОЙ ЖЕЛЕЗЫ С ДИСТАЛЬНЫМ ПАНКРЕАТОЕЮНОАНАСТОМОЗОМ ПО РУ У РЕБЕНКА. МеДИЦИнСКИЙ вестник СеверноГО Кавказа. 2019;14(3):547-550. DOI - https://doi.org/10.14300/mnnc.2019.14137

CT - computed tomography

ERCP - endoscopic retrograde cholangio-pancreatography

MRI - magnetic resonance imaging

ancreatic pseudocysts are quite rare in pediatric practice. There are many types of surgical treatment suggested for the management of pancreatic pseudocysts that have shown good results both in adult and pediatric surgery [1-5]. The authors present a clinical case of a child with a pancreatic post-traumatic pseudocyst successfully treated with laparoscopic distal pancreatojejunostomy.

Clinical Case of a 7-year-old boywith a blunt abdominal injury admitted to the local hospital where he underwent a laparotomy, on which it found a complete transverse rupture of the pancreatic isthmus. The drainage finished the surgery to the lesser sac. When the drainage was removed, the pancreatic cyst has formed and has been growing rapidly, correlating with the child's complains of severe pain. Conservative treatment was ineffective. On admission to our hospital four months after the trauma, an ultrasound revealed a fluid formation with a diameter of $55 \mathrm{~mm}$ located in the pancreatic body. Abdominal CT revealed in the lesser sac the cyst up to $6 \mathrm{~cm}$ in diameter

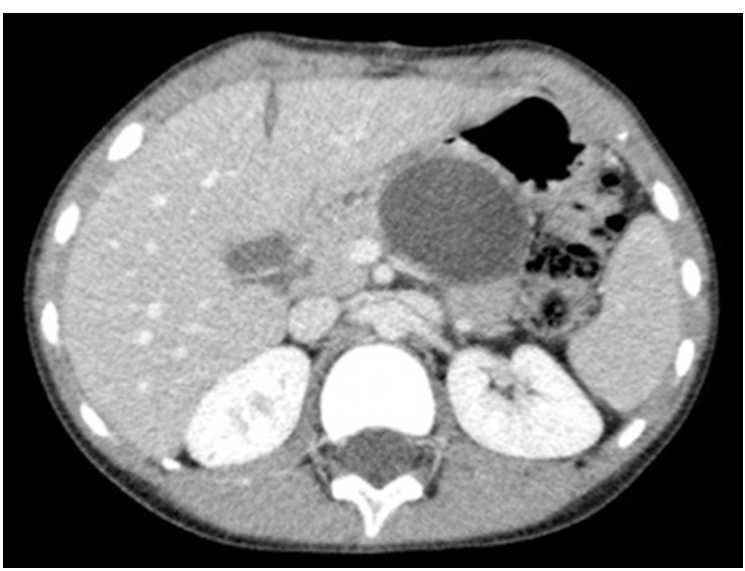

Fig. 1. CT: pancreatic cyst up to $4 \mathrm{~cm}$ in the lesser peritoneal sac between the fragments of the pancreas

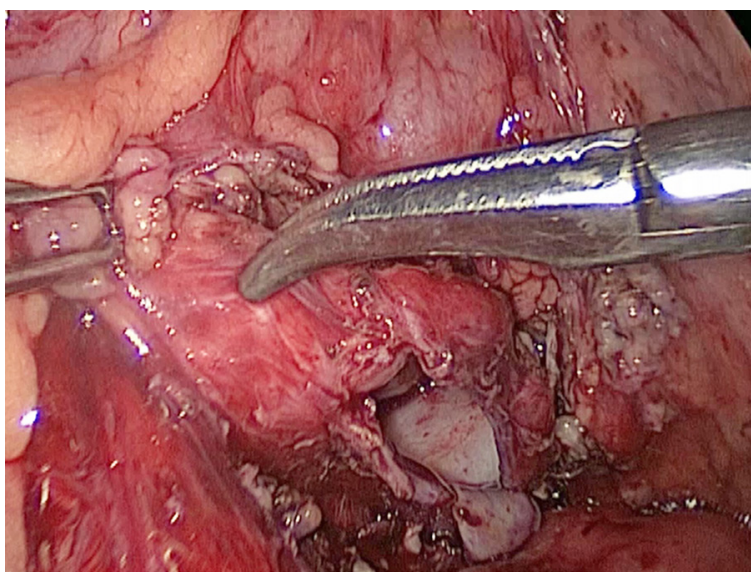

Fig. 2. Laparoscopy. Tense cyst in the omentum in front of the pancreas, which was located on the site of the isthmus of the pancreas and dividing the pancreas into two fragments (Fig. 1). Laparoscopy showed the lesser sac containing the cystic lesion with a diameter of $6 \mathrm{~cm}$ with walls of about $2 \mathrm{~mm}$ thick. The cyst opened. A clear transparent liquid was released under pressure (Fig. 2). Cystic walls were excised partially by EnSeal with preserving the fibrous tissue on the pancreatic head stump (Fig. 3). The distal gland fragment separated from the superior mesenteric and splenic veins. Using the ENDO GIA TM Universal stapler, the jejunum crossed transversely on $20 \mathrm{~cm}$ from the Treitz ligament. The apparatus intestinal anastomosis «side to side» was done; a Roux-en-Y loop of $25 \mathrm{~cm}$ long was formed and put behind the colon to lesser sac. An invaginated distal pancreaticojejunal anastomosis was done with a PDS II 5/0 interrupted intracorporeal sutures (Fig. 4). The lesser sac drained. The postoperative period was uneventful. Enteral feeding started on day fifth. The drain removed on day seventh. Three years of follow up after surgery revealed no complaints.

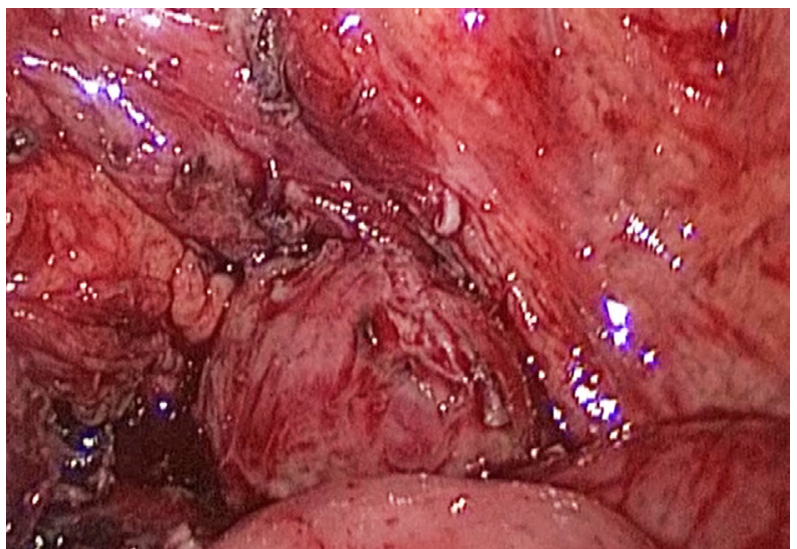

Fig. 3. Laparoscopy. Pancreatic head stump with fibrous tissue

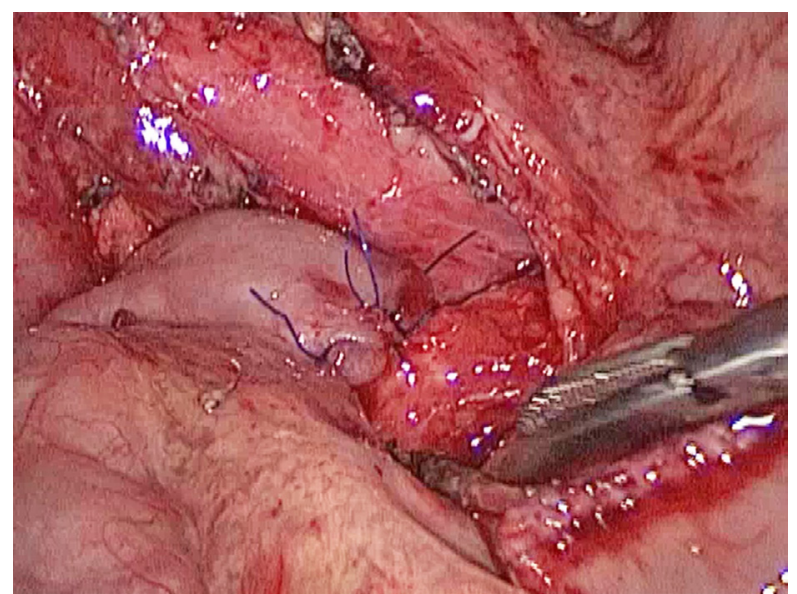

Fig. 4. Laparoscopy. Distal Roux-en-Y pancreato-jejunal anastomosis 
Discussion. Pancreatic pseudocysts in children are relatively rare, although they result in up to $75 \%$ of all cystic pancreatic lesions [1, 2]. Pancreatic secret in lesser sac as a result of traumatic or inflammatory cause leads to development encapsulation and formation of the thick wall cystic cavity with no epithelial lining $[1,3,4]$. The etiology of pancreatic pseudocysts is diverse. The most of them in children are post-traumatic pseudocysts, less often post-necrotic as a complication of acute pancreatitis. When it is not possible to find the etiology of the cyst, it can be called an idiopathic pancreatic cyst [1-3, 5-7].

The clinical picture in pancreatic pseudocysts by the etiology and size of the cyst is determined. With an enlarging of the pseudocysts, a pain, nausea, vomiting, intestinal obstruction, obstructive jaundice can occur $[1,5,8,9]$. In addition to the above complications, there are reports of observations of infection, rupture, bleeding inside the cyst [10]. All this can be an indication for surgical treatment.

For the diagnosis of pancreatic pseudocysts, the transabdominal ultrasound is used. In most cases allows evaluating the size, topography, wall thickness, and contents of the cyst, as well as the condition of the pancreatic parenchyma and the surrounding organs. However, the origin of the giant cysts is not always obvious. CT is the most informative imaging method allowing finding the exact size, location, and relationship of pseudocysts with the other organs. To increase the specificity of the technique, it is possible to use oral and (or) intravenous contrast [2, 4]. MRI in the mode of cholangiopancreatography allows to evaluate the relationship of the cyst with the main pancreatic duct, bile ducts, as well as the homogeneity of the MR signal reveals the absence/presence of tissue detritus inside the cyst $[2,10]$.

ERCP can reliably assess the relationship of the cyst with the duct system that influences the decision in the choice of surgical treatment. However, its use in children is minimal due to the anatomical size and high reactivity of the pancreas $[6,7]$.

The treatment of pancreatic pseudocysts by the duration of the disease, the size, and localization of the pseudocyst and clinical manifestations is determined. Conservative treatment is usually effective in the early stages of pancreatic pseudocyst formation, in the absence of pain and intensive growth and size up to $6 \mathrm{~cm}$ [11]. In the case of fast-growing "young» pseudocysts after noneffective conservative therapy, external draining can be used under the guidance of ultrasound or laparoscopy. The use of this method in the case of long-existing pseudocysts leads to relapse and pancreatic fistula at the site of drainage in a large percentage of cases [12].
The methods of internal drainage by providing the anastomosis between the cyst and the gastrointestinal tract (stomach, duodenum, or jejunum) have become more popular $[5,6,12]$. Until recently, the most popular methods for curing the pancreatic pseudocysts were internal draining by the cystogastro- or cystojejunal anastomosis that allowed achieving the reliable longterm drainage of the contents into the gastrointestinal tract has a low relapse level, and a shorter hospital stays compared to external drainage. Another advantage of this technique is the possibility of full revision of the abdominal cavity with the visualization of the lumen of the cyst that is helpful in case of the difficult differential diagnosis. Such treatment can be complicated by anastomositis in the early postoperative period in a few cases [4].

In the practice of adult general surgeons, the endoscopic transgastric drainage became relatively popular [6, 7]. Recently, there are some publications on the use of such methods in children. The advantages include minimally invasiveness, faster patient recovery, relatively low cost of the procedure, less need in prolonged anesthesia. Endoscopic procedures can be complicated by bleeding, intestinal perforation, blocking and migration of the stent and relapse of the cyst, and also have limitations with cysts wall thicknesses more than $1.0 \mathrm{~cm}$ and location of the cyst in the head or isthmus of the pancreas $[6,7,8]$.

In our case of a child with the complete transverse rupture of the main pancreatic duct, a rapidly growing cystic cavity was formed, completely dividing the pancreatic parenchyma into two parts. External drainage considered to be ineffective and subsequently could lead to fibrosis and loss of function of the large part of the distal pancreatic fragment. That was the reason why an organ-preserving surgery was chosen: the patient underwent the laparoscopic partial cystectomy with the distal Roux-en-Y pancreaticojejunal anastomosis. There are only a few publications of similar laparoscopic procedures in children $[3,4,11,13]$.

Thus, from the whole variety of existing surgical treatment modalities in case of pancreatic pseudocysts, the surgical choice should be determined individually depending on the size and location of the pseudocyst, the time of its occurrence and the relationship of the cyst with the pancreatic duct system, as well as the experience and capabilities of the hospital. In the case of pseudocysts formed after the trauma with total duct rupture located in the pancreatic isthmus, a laparoscopic partial cystectomy with the distal Roux-en-Y pancreaticojejunal anastomosis can be the method of choice.

Disclosures:

The authors declare no conflict of interest.

References

1. Corte D. C., Faraci S., Majo F., Lucidi V., Fishman D. S. Pancreatic disorders in children: New clues on the horizon. Digestive and Liver Disease. 2018:50(9):886-893. https://doi.org/10.1016/j.dld.2018.06.016

2. VisserB.C.,MuthusamyV.R., YehB.M.Diagnosticevaluation of cystic pancreatic lesions. HPB (Oxford). 2008;10(1):6369. https://doi.org/10.1080/13651820701883155

3. Sokolov Yu. Yu., Tumanyan G. T., Ol'khova E. B. [et al.] Laparoscopic surgery in children with pancreatic pathology. Rossiyskiy Vestnik detskoy khirurgii, anesteziologii i reanimatologi. 2015;5(3):14-19.

4. Yoder S. M., Rothenberg S., Tsao K. [et al.] Laparoscopic treatment of pancreatic pseudocysts in children. J. Laparoendosc. Adv. Surg. Tech. A. 2009;19(1):37-40. https://doi.org/10.1089/lap.2008.0124.supp

5. Bhattacharya D., Ammori B. J. Minimally invasive approaches to the management of pancreatic pseudocysts: review of the literature. Surg. Laparosc. Endosc. Percutaneous Tech. 2003;13(3):141-148.
6. Sharma S. S., Maharshi S. Endoscopic management of pancreatic pseudocyst in children-a long-term follow-up. J. Pediatr. Surg. 2008;43(9):1636-1639. https://doi.org/10.1016/j.jpedsurg.2008.01.026

7. Shanafey S., Shun A., Will S. Endoscopic Drainage of Pancreatic Pseudocysts in Children. Journal of Pediatric Surgery. 2004;39(7):1062-1065. https://doi.org/10.1016/j.jpedsurg.2004.03.071

8. Alzaiem M., Zaiem F., Zaiem F. Congenital pancreatic pseudocyst presenting as neonatal ascites. J. Ped. Surg. Case Reports. 2016;11:44-46. http://dx.doi.org/10.1016/j.epsc.2016.06.002

9. Sokolov Yu. Yu., Korovin S. A., Tumanyan G. T., Dzyadchik A. V., Kirgizov I. V. [et al.] Effectiveness of laparoscopic interventions in children with intestinal intussusception. Medical News of North Caucasus. 2017;17(2):131-134. https://doi.org/10.14300/mnnc.2017.12037

10. Ramos-Gonzalez G. J., Medfordb S. D., Kima H. B. Transduodenal cystoduodenostomy for pancreatic pseudocyst in two young children. Journal of Pediatric Surgery. Case 
Reports. 2018;34:20-22.

https://doi.org/10.1016/j.epsc.2018.04.017

11. Tsuman V. G., Mashkov A. E., Sigachev A. V. [et al.] Tactics of treating children with acute pancreatitis complicated by pancreatic fistulas and pseudocysts. Rossiyskiy Vestnik detskoy khirurgii, anesteziologii i reanimatologi. 2016;4(2):6-12.

12. Saad D. F., Gow K. W., Cabbabe S. Heissa K., Wulkana M. L. Laparoscopic cystogastrostomy for the treatment of pancreatic pseudocysts in children. Journal of Pediatric Surgery. 2005;40:13-17.

https://doi.org/10.1016/j.jpedsurg.2005.07.041

13. Anadolulu A., Kafadar M. T., Gök M. A., Anadolulu Z. Laparoscopic spleen-preserving distal pancreatectomy with splenic vessel preservation for pancreatic pseudocyst in a 10-year-old boy. Journal of Pediatric Surgery Case Reports. 2018;34:10-12. https://doi.org/10.1016/j.epsc.2018.04.011

\title{
About authors:
}

Sokolov Yuriy Yur'evich, MD, PhD, Professor, Head of the Department of pediatric surgery; tel.: +9857743280; e-mail: sokolov-surg@yandex.ru

Efremenkov Artem Mikhaylovich, MD, Assistant of Professor of the Department of pediatric surgery; tel.: +79153001556; e-mail: efremart@yandex.ru

Tumanyan Grachik Tatevosovich, MD, PhD, Professor; +79032610790; e-mail: tymanyan@list.ru Shapkina Anna Nikolaevna, MD, Associate Professor; tel.: +79147037589; e-mail: pedsurg2005@mail.ru Akhmatov Roman Anatol'evich, MD, Resident of the Department of pediatric surgery; tel.: +79157327525; e-mail: romaahmatov@yandex.ru Antonov Dmitriy Valer'evich, MD, PhD, Associate Professor; tel.: +79024729727; e-mail: podkb1@mail.ru

(C) Group of authors, 2019

UDC 617.713-007.64

DOI - https://doi.org/10.14300/mnnc.2019.14138

ISSN - 2073-8137

\section{REPLACING POLYMERIC CORNEAL RING SEGMENTS WITH ALLOGENIC BANDAGE IN PATIENT WITH PROGRESSING KERATOCONUS (A CLINICAL CASE STUDY)}

\author{
Sheludchenko V. M. ${ }^{1}$, Osipyan G. A. ${ }^{1,2}$, Youssef N. Yo. ${ }^{1,2}{ }^{2}$ Khraystin Kh. ${ }^{1}$, Dzhalili R. A. ${ }^{1}$ \\ ${ }^{1}$ Research Institute of Eye Diseases, Moscow, Russian Federation \\ ${ }^{2}$ Center Vision Recovery, Moscow, Russian Federation
}

\section{ЗАМЕНА РОГОВИЧНЫХ СЕГМЕНТОВ ИЗ ПОАИМЕРНОГО МАТЕРИААА НА АААОБАНААЖ ПРИ ПРОГРЕССИРОВАНИИ КЕРАТОКОНУСА (КАИНИЧЕСКОЕ НАБАЮАЕНИЕ)}

\author{
В. М. Шелулченко ${ }^{1}$, Г. А. Осипян ${ }^{1,2}{ }^{2}$, Н. Ю. Юсеф ${ }^{1,2}{ }^{2}$ Х. Храйстин ${ }^{1}$, Р. А. Ажалили ${ }^{1}$ \\ ${ }^{1}$ Научно-исслеАовательский институт глазных болезней, Москва, \\ Российская ФеАерация \\ 2 Центр восстановления зрения, Москва, Российская ФеАерация
}

\begin{abstract}
Keratoconus is a serious problem for patients, which is accompanied by a decrease in visual functions and the progression of ectasia. The original bandage therapeutic-optical keratoplasty technique (intracorneal implantation of a wide allotransplant formed by femtolaser) allows long-term preservation of high visual function and management of keratectasia in a patient with keratoconus and corneal ectasia when routine methods (ICRS, cross-linking) are ineffective. Formation of the bandage led to improvement of visual function and cease of ectasia progression.
\end{abstract}

Keywords: keratoconus, bandage keratoplasty, implantation of intrastromal corneal ring segments, femtosecond laser, BTOK

Кератоконус является серьезной проблемой для пациента и сопровождается снижением зрительных функций с прогрессированием эктазии роговицы. В клиническом случае представлено применение метода бандажной лечебно-оптической кератопластики по собственной методике (интракорнеальная имплантация фемтосформированного широкого аллотрансплантата) у пациента с эктазией роговицы при кератоконусе и несостоятельности рутинных методов лечения. Данный подход позволил добиться длительного сохранения высоких зрительных функций и сдерживания кератоэктазии.

Ключевые слова: кератоконус, бандажная лечебно-оптическая кератопластика, имплантация интрастромальных роговичных сегментов, фемтосекундный лазер, операция «БЛОК» 